\title{
In Memory of Volodymyr Morenets
}

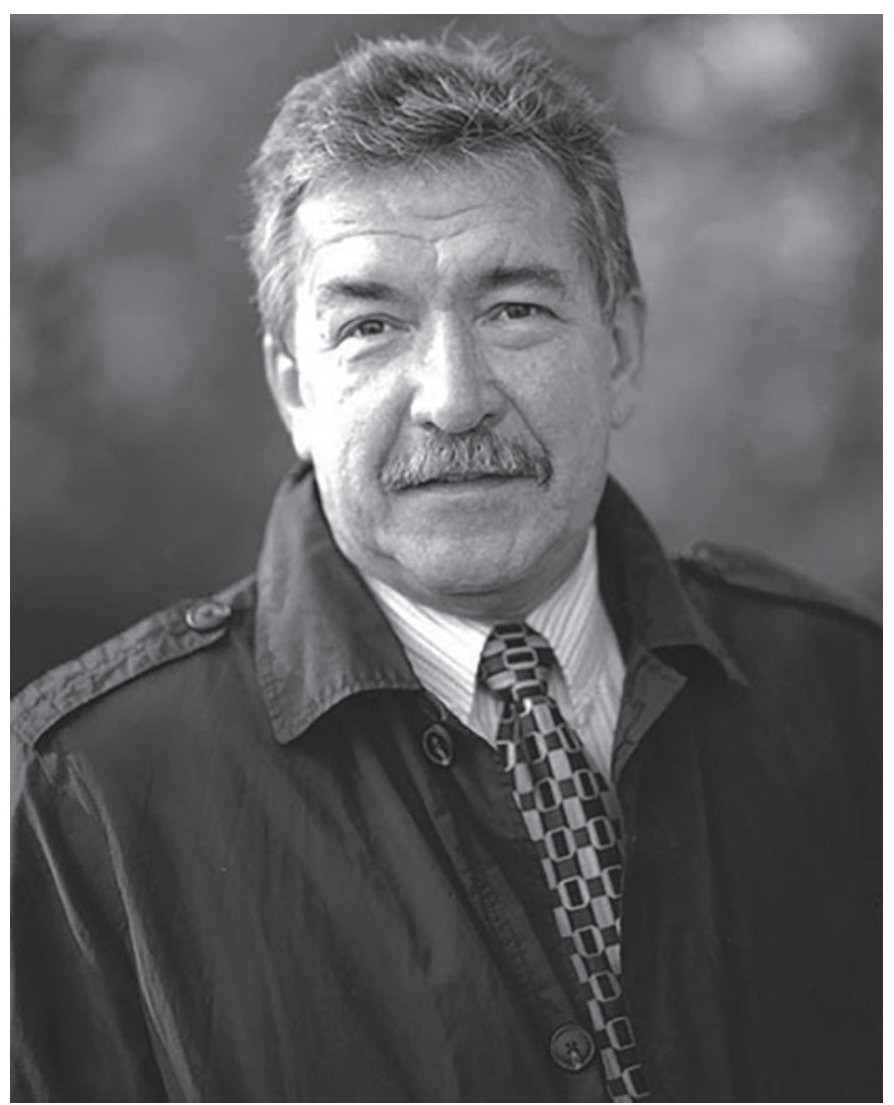

On June 28, 2021, the editor-in-chief of the Kyiv-Mohyla Humanities Journal passed away. Over the past decade Volodymyr Morenets had conceptualized, developed, and formulated the principles of our publication. Doctor of Philology, Professor, wellknown literary critic, author of monographs and numerous articles on the history of Polish and Ukrainian literatures, laureate of the Taras Shevchenko National Prize, Merited Worker in the Sciences and Technologies of Ukraine, Head of the Department of Literature at the National University of Kyiv-Mohyla Academy, Volodymyr Morenets was one of the builders of the Academy, its former Dean, Vice President, and Acting President.

Volodymyr Morenets was born on June 9, 1953 into a family of philologists of many generations. He graduated from the Faculty of Philology at the Taras Shevchenko National University of Kyiv in 1975, where he had studied Polish and Ukrainian languages and literatures at the Department of Slavic Studies since 1970.

During this period, from 1973 to 1974, he completed an internship at the University of Warsaw, where he improved his Polish-language skills, conducted research, and communicated with representatives of the Polish intellectual elite, who at that time functioned in less restricted surroundings than did their Ukrainian colleagues. 
In 1974, one of the most important results of Volodymyr Morenets' internship in Poland was presented as a publication in the journal Knowledge and Work - a substantial interview with Stanislaw Lem, which for an ambitious young literary critic represented a victory over himself and circumstance. However, back home, the Polish episode and previous "ideological deviations" hampered the development of the academic career of talented young scholar, resulting in posts outside of his specialty. From 1975 to 1977, Volodymyr Morenets worked as a laboratory assistant at the Institute for the Advanced Training of Teachers of Social Sciences at the Taras Shevchenko National University of Kyiv, and from 1977 to 1982 he was a literary associate of the journal "Economics of Soviet Ukraine." It was in 1979 that Volodymyr Morenets finally began a 17-year period of professional activity at the Taras Shevchenko Institute of Literature at the National Academy of Sciences of Ukraine.

From 1979 to 1982 Volodymyr Morenets studied at the Literature Institute's School of Postgraduate Studies, successfully defending his $\mathrm{PhD}$ dissertation, entitled "Sources of the Poetics of Konstanty Ildefons Gatczyński," devoted to the literature of Polish modernism, in 1982. That year Volodymyr Morenets was also admitted to the Writers' Union of Ukraine as a critic. In the early 1990s, he became one of the founders of a new writers' association, the Association of Ukrainian Writers (AUP), of which he was elected Vice President in 1997.

From 1983 to 1987 Volodymyr Morenets was as a researcher at the Taras Shevchenko Institute of Literature and was on staff at the journal Soviet Literary Studies (today Slovo i Chas), where he headed the criticism and bibliography section. At the Institute of Literature he subsequently moved to the Department of 2oth Century Ukrainian Literature, where in 1989 he entered the Institute's doctoral program, which in 1994 resulted in the successful defense of his doctoral dissertation, entitled Modern Ukrainian Poetry: Patterns of Development and the Logic of its SelfPropulsion.

Also in 1996, Volodymyr Morenets became laureate of the Taras Shevchenko National Prize as a member of Vitalii Donchyk's team of authors in the publication of A History of Ukrainian Literature of the Twentieth Century in 2 volumes (Kyiv: Lybid, 1993-1995), the first post-Soviet publication that presented as fully as possible, in regard to individuals and phenomena, a theoretically structured history of zoth century Ukrainian literature.

1996 represented a turning point in the biography of Volodymyr Morenets, the beginning of a quarter-century marathon in the building of the National University of Kyiv-Mohyla Academy, in particular, its Department of Philology. On November 19, 1996, Volodymyr Morenets headed the Department of Philology (today the Department of Literature), which was established through the amalgamation of the Departments of Foreign Languages and World Literature and Comparative Studies.

Parallel to the development of philological studies at NaUKMA, Volodymyr Morenets, then as Dean of Master's studies, focused his administrative efforts on the 
establishment of new master's programs, whose number in result was significantly increased.

The development of a new generation of scholars became the next important task for Volodymyr Morenets in his positions as Vice President for Research (20032005; 2006-2011) and Vice President for Academic Affairs (2005-2006). As Chair of NaUKMA's Publishing Council (2003-2015) he ensured the implementation of international research projects, and the publication of collective and individual monographs and periodicals.

Also at NaUKMA, he headed the editorial boards of Naukovi zapysky NaUKMA. Filolohichni nauky (literaturoznavstvo) (1998-2017; NaUKMA Research Papers. Philology (Literary Studies)), Naukovi zapysky NaUKMA. Literaturoznavstvo (20182019; NaUKMA Research Papers. Literary Studies), and Mahistetium. Literaturoznavchi studii (1999-2017; Magisterium. Literary Studies). He was a member of a number of editorial boards outside of NaUKMA, including the literary journal Slovo $i$ Chas and the legendary journal Suchasnist. Volodymyr Morenets was also editor-in-chief of scores of thematic collections and collective monographs in the humanities.

As Vice President for Research, Volodymyr Morenets, together with colleagues and international partners, began to develop, within a TEMPUS project, a model for doctoral school $(\mathrm{PhD})$ programs that led to the establishment of a Doctoral School at NaUKMA implementing structured $\mathrm{PhD}$ programs, which took place from 2008 to 2015. Volodymyr Morenets made the development of international cooperation for NaUKMA a priority in a variety of other programs, and twice received support as a fellow of the Fulbright Academic Exchange Program (1999, 2007-2008).

The next stage of Volodymyr Morenets' activity at NaUKMA was in the positions of first Vice President and Vice President for Academic Affairs (2011-2014). At that time, he took an active part in the preparation of an alternative to the then in place Law "On Education," the new version being adopted in post-Maidan Ukraine by the Verkhovna Rada of Ukraine in September 2014.

From March 3, 2014 to December 15, 2014, Volodymyr Morenets served as Acting President of NaUKMA. After having ensured the holding of elections for a new NaUKMA president, he returned to the posts of First Vice President and Vice President for Academic Affairs, serving until April 1, 2015. In June 2015, Volodymyr Morenets again headed the Department of Literature, focusing on the next stage of the development of a "Mohyla approach" to literary studies.

Volodymyr Morenets took an active part in the training of academic staff as chair (2008-2016, NaUKMA) and member (1996-2003, Taras Shevchenko Institute of Literature) of specialized academic councils pertaining to $\mathrm{PhD}$ and doctoral dissertation defenses. He was also a member (1998-2004) and chair (2000-2004) of the Expert Council of the Higher Attestation Commission of Ukraine. In total, Volodymyr Morenets was adviser on $10 \mathrm{PhD}$ and doctoral dissertations in philological studies.

In recent years, an important area of Volodymyr Morenets' activity was the dissemination of knowledge of the humanities sphere in other professional 
environments, in particular in the business community. His cooperation with the KyivMohyla Business School (KMBS) resulted in his involvement in a number of KMBS educational projects and publication programs.

An excerpt from an interview in 2013 with Volodymyr Morenets is indicative of the scholar's wit and wisdom: "Everything that keeps me here and surrounds me will continue to exist when I'm gone: the laughter won't stop, and even the frailest antenna on a roof or the smallest leaf on a chestnut tree won't flinch when I'm gone. That's how it should be, as otherwise - what's it all for? In fact, what breeds you does not belong to a particular time, and will last beyond time, the time allotted for you." As will continue to exist what Volodymyr Morenets bred and created.

\section{Nataliia Peleshenko}

National University of Kyiv-Mohyla Academy 